\title{
Visuality and Sexual Difference in Maupassant's "Mademoiselle Fifi"
}

\section{Ritt Deitz}

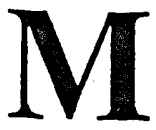

aupassant's use of visual descriptions and the visual sense. a phenomenon one might call "visuality" in narrative fiction. is pervasive in his shorter works, his novellas and his novels. His reliance on visuality very often appears to have as its goal the elucidation of the differences that permeate his fictional worlds, be they perceptual, social or sexual. It is this latter distinction that most solidly informs the textual universe of the short story "Mademoiselle Fifi".

The act of central narrative importance in "Mademoiselle Fifi", a prostitute"s banquet-table murder of a Prussian officer during the Franco-Prussian War, is basically constructed on a series of visual events. Although it is in many ways the most climactic aspect of the narrative, the relationship between the characters of Wilhem d'Eyrik and the prostitute Rachel is not the main axis on which Maupassant builds his representation of sexual difference. The murder and the figure of Rachel certainly involve some differential representations of gender and sexuality, but it is the development of the character of Eyrik that offers the most to those interested in gender representation in Maupassant's work. The first part of this reading will investigate visuality, principally, in the following two areas: representations of Eyrik's ambiguous sexuality and physical descriptions of his assassin, the prostitute Rachel. In the second stage of this analysis I will address the figure of the hole, which permeates the text, and its narrative relevance in the greater context of visuality and sexual difference in "Mademoiselle Fifi".

First let us examine the sexually ambiguous narrative construction of Eyrik. The narrator's first description of him is the following: "le marquis Wilhem 
d'Eyrik, un tout petit blondin fier et brutal avec les hommes, dur aux vaincus, et violent comme une arme a feu" (386). This sentence, in spite of the diminutive "tout petit", is a traditionally masculine representation of the soldier: proud, brutal, hard, violent. It is, however, in the following paragraph that the sexual ambiguity of the character is introduced, through his nickname:

Depuis son entrée en France, ses camarades ne l'appelait plus que Mlle Fifi. Ce surnom lui venait de sa tournure coquette, de sa taille fine qu'on aurait dit tenue en un corset, de sa figure pâle où sa naissante moustache apparaissait à peine, et aussi

de l'habitude qu'il avait prise, pour exprimer son souverain mépris des êtres et des choses, d'employer à tout moment la locution française $-f i$, $f i$ donc , qu'il prononçait avec un léger sifflement. (386-87)

The use of the imparfait and plus-que-parfait verb tenses makes a narrative stop of this descriptive passage; they serve simply to recuperate information necessary to later narrative logic. But what is most interesting about this visual description is the femininity of Eyrik's physique. His "tournure coquette" and "taille fine" remind one of femaleness, as does Eyrik's appearance of wearing a corset. The pale skin of his face, a classic sign of femininity in Maupassant, recalls descriptions of Jeanne as a young girl in Une vie. Eyrik's barely visible moustache puts him in the physical category of women and adolescent boys, but certainly not in that of Maupassant's virile male characters. Eyrik's final descriptive quality, the vocalic enunciation of the French expression that explains his name, has no particular connotative value in and of itself. However, because it is preceded by the aforementioned visual markers of femininity, Eyrik's habit of switching from German to the finicky-sounding " $\mathrm{fi}$, $\mathrm{fi}$ donc" is cast as a decidedly feminine gesture.

The narrator's subsequent mixing of the masculine and feminine subject pronouns $i l$ and elle, enabled by the frequent use of the feminine nickname, charges Eyrik with a strangely flexible gender status. Uncertainty as to Eyrik's sexual identity is due not only to this pronominal gender switching, but also to the violent behavior of the character himself. This discomfort is evident in the following sequence, in which Eyrik fires his gun at one of the oil paintings he has already defaced with coal:

Mlle Fifi elle-même ne semblait pas tenir en place. Elle se

levait, se rasseyait. Son oeil clair et dur cherchait quelque chose à briser. Soudain, fixant la dame aux moustaches, le jeune blondin tira son revolver.

"Tu ne verras pas cela toi », dit-il; et sans quitter son siège, il visa. Deux balles successivement creverent les deux yeux du portrait. (339)

The actual gender of the subject here is feminine for the entire first two sen- 
tences (elle), referring of course not to the actual sex of Eyrik but to the "sex" of his name. It is not until the passage's third sentence, in which Evrik is renamed as the masculine-gendered "jeune blondin", that Eyrik recuperates the masculine pronoun $i l$. The switch from elle to $i l$ occurs at the moment of narrative re-ignition - that is, at the moment when the narrator drops the imparfait for the linear, moment-bound specificity of the passé simple: "Soudain [...] le jeune bondin tira son revolver". The moments of narrative action-the pulling of the gun, the speaking, the aiming, the shooting - all fall into the domain of the pronoun il.

The ambiguity of Eyrik's sexual presence is also a result of juxtaposition with other characters-specifically with the fatherlike major commandant. who is after all the first character to appear in the text. The sequence in which Eyrik engineers the explosion of a Chinese teapot for the amusement of his fellow Prussian officers is a good example of this contrastive gender play:

Mlle Fifi, entrée la première, battait les mains avec délire devant une Vénus de terre cuite dont la tête avait enfin sauté; et chacun ramassa des morceaux de porcelaine, $s^{*}$ étonnant aux dentelures étranges des éclats, examinant les dégâts nouveaux. contestant certains ravages comme produits par l'explosion précédente: et le major considérait d'un air patemal le vaste salon bouleversé par cette mitraille à la Néron et sablé de débris d’objets d’art. Il en sortit le premier, en déclarant avec bonhomie : "Ça a bien réussi, cette fois. " (389)

The narrator again chooses to call Eyrik by his feminine nickname, which permits the feminization of the past participle "entree". Eyrik"s presence in the paragraph is counter-balanced by the major's in several ways. Whereas Eyrik. in all his hysterical hand-clapping enthusiasm, is represented in the beginning of the paragraph, the major is at the end. Both characters are the first to do something-"Mlle Fifi, entrêe la première " and "le major [...] en sortit le premier" (emphasis added) - but it is the gender switch in the word "premier" itself that indicates difference between the two characters. The narrator's indication of the major's glance as masculine and paternal-"le major considérait d' un air paternel le vaste salon"intersexual identity.

The narrator employs other descriptions of Eyrik's relationship to the major. outside the domain of visual description, that put the subordinate officer's actual sexual identity in question. For example, Eyrik's attempts to convince the major to order the ringing of the town church bells are described as a series of coquettish, playful pleas:

[...] et chaque jour il suppliait le commandant de le laisser faire

" Ding-don-don ", une fois, une seule petite fois pour rire un peu

seulement. Et il demandait cela avec des grâces 
de chatte, des cajoleries de femme, des douceurs

de voix d'une maîtresse

affolee par une envie [...] (390-91)

By his explicit comparison of Eyrik's behavior with that of a mistress, the narrator virually establishes the latter's identity as female in relation to the text's hierarchy of male characters.

The reader finds no reference whatsoever to Eyrik's eyes until the passage in which he shoots the portrait. This first description appears to indicate the cold determination of the character in his choices and actions: "Son oeil clair et dur cherchait quelque chose a briser" (388). This fragment echoes the first description of Rachel, the prostitute who will eventually murder Eyrik: "Rachel, une brune toute jeune, à l'oeil noir comme une tache d'encre" (392). Like Eyrik, Rachel's dark temperament first appears in her eyes. After the officer forcibly kisses her for the first time, she reacts unfavorably: "Soudain, Rachel suffoqua, toussant aux larmes [...] Elle ne se fâcha point, ne dit pas un mot, mais elle regarda fixement son possesseur avec une colère éveillée tout au fond de son ocil noir" (392). Like Eyrik's, Rachel's eyes serve as a sign of potential violence in this description.

One must return to the narrator's first description of Rachel to see how sexuality and visuality contribute to the narrational inevitability of violence in the text. Having brought all the women into the château, the Baron de Kelsweingstein introduces them and pairs them with the other waiting officers:

Ayant ensuite embrassé Blondine, la seconde, en signe de propriété, il offrit au lieutenant Otto la grosse Amanda, Éva la Tomate au sous-lieutenant Fritz, et la plus petite de toutes, Rachel, une brune toute jeune, à l'oeil noir comme une tache d'encre, une juive dont le nez retroussé confirmait la règle qui donne des becs courbes à toute sa race, au plus jeune des officiers, au frêle marquis Wilhem d'Eyrik. (392)

Narrative flow, while present in the baron's act of "distributing" the women to his colleagues, is stopped in the passage's descriptions of Rachel and Eyrik. Both characters, who will quickly become the two most significant characters in the playing out of the narrative, are described as "jeune". Rachel, as already mentioned above, is immediately marked by blackness and darkness ("une brune [...] a l'oeil noir [...] etc.") and is thus associated with the mysterious and the uncontrollable. Maupassant's racist generalization about the curved shape of Rachel's nose being a mark of her Jewishness also makes her appear unpredictable to the late nineteenth-century French reader, in that she is doubly "foreign" to mainstream society: she is both a prostitute and a Jew. Perhaps the key word in this fragment, though, is "frêle". This adjective, especially in light of his "partner's" description, immediately marks Eyrik's vulnerability to whatever potential Rachel possesses. 
Eyrik and Rachel are thus caught, by the narrator's carefully constructed network of visual descriptions, in a kind of movement toward physical confrontation. Woven into these various visual descriptions of characters and events-so very fundamental in this text's cumulative implication of impending violenceare equally important descriptions of certain objects. Arguably, the most symbolically charged of these objects is the figure of the hole.

If the ambiguity of sexuality in visual representation is like a road across the text's narrative, then the text's descriptions of holes are like stop signs along that road: although they are irrelevant to the destination itself (imaginable portraits of characters' sexual identities and behaviors). they nonetheless drau much attention to the process of getting there. It is indeed in the "getting there"-in this case, the highly descriptive weaving of a murder, in a specific context, across a large number of narrative breaks - that visual analysis mos directly involves the figure of the hole. In this text, holes find their primar: symbolic value in figures other than that of androgyny or binary sexual pairing. They basically work, in their visual status, as formal echoes of the homicidal act itself.

Holes are associated, in the very first paragraph of the text. with the major commandant's physique and activities, and are thus linked by metonymy to both occupation and destruction:

Le major, commandant prussien, comte de Farlsberg. acherait

de lire son courrier, le dos au fond d'un grand fauteuil de

tapisseric et ses pieds bottés sur le marbre élégant de la

cheminéc, où ses éperons, depuis trois mois qu'il occupait

le château d'Uville, avaient tracé deux trous profonds, fouillés

un peu plus tous les jours. (385)'

The major's spurs, with their regular digging into the voluptuous physical entironment of the château, may aiso be read as an ironic political wink to the bourgeois reader; the spurs themselves can be read as a metaphor for the ruthles: Prussian victory over the technologically underdeveloped yet aesthetically refined French nation in 1870-71. 1

But this passage is most useful as a function of the text's internal visual economy: it serves as the first of a number of visual descriptions of holes that cumvlatively echo the narrator's descriptions of Rachel, as well as her physical gesture as she murders Eyrik. Another component of this cumulative echo effet is Eyrik's destruction of the moustached portrait, already cited above ("Deux balles successivement creverent les deux yeux du portrait"). That Eyrik makex two holes does seem somewhat relevant here, since the approaching banquet scene and the murder itself have at their center the binarity of male-female relations. The blown-out eyeholes rather convieniently echo the "deux trous profonds" the major has dug into the marble, without drawing attention to the nar. rative voice itself. But the textual component that contrasts most obviously 
with this duality is the description of Rachel's eyes, twice described: "une brune toute jeune, d l'ceil noir ", "elle regarda fixement son possesseur avec une colère éveillée tout au fond de son oeil noir " (392; emphasis added). The narrator, by representing the heroine's two eyes through synecdoche as a single "oeil", intrudes on visual verisimilitude and thus puts his own work in relief, creating a kind of textual shock. One must split this "oeil noir" in two in order to achieve a "realistic" image of Rachel, almost immediately conjuring the two bullet-torn eyes of the earlier sequence. In his Journal du regard, Bernard Noël offers a model, useful in the analysis of this scene, for visual participation in art:

Dans toute oeuvre visuelle, la visibilité est le résultat du

travail obscur de la main [...] Cette visibilité voyage à travers

le corps, de l'oeil à la main, puis entre dans le regard. (28)

Maupassant's narratorial intervention-the literary equivalent of Noël's "travail obscur de la main"-makes a crisis of the reader's position in this scene, because the latter must recognize his/her own role in the visualization of the text's described objects. Like Noël's artis//spectator, the reader takes possession of a "regard" that recognizes the work of narrative inscription-in this case, the mounting of an indirect visuality. The narrator's mention of a single "ocil" in this way neutralizes the effect of realism in the sequence by highlighting a rhetorical obstacle to the reader's visualization of Rachel. Maupassant thus signals the presence of the reader in the decoding process.

In a similar operation, the depth-the "fond" —of Rachel's "eye" finds a formal, albeit avisual, echo in the hiding place of the only heirloom safely hidden by the fleeing château owner:

En quittant son château, le propriétaire légitime, le comte

Fernand d'Amoys d'Uville, n'avait eu le temps de rien emporter

ni de rien cacher, sauf l'argenterie enfouie dans le trou d'un

mur. (388-89)

The hidden silver, as the only object of finery safe from the destructive whims of the bored officers, also prefigures the miraculous safety Rachel will find in the village clock tower after her assassination of Wilhem d'Eyrik. The holedaway silver finds a further figurative attachment to Rachel in the text's last paragraph, in which the narrator explains her fate:

Elle en fut tirée quelque temps après par un patriote sans

préjugés qui l'aima pour sa belle action, puis l'ayant ensuite

chérie pour elle-même, l'épousa, en fit une Dame qui valut

autant que beaucoup d'autres. (397)

By the end of the story, Rachel, the recently liberated "silver" so long hidden in the "hole" of the clock tower, is re-valued, upgraded in worth by her marriage to an unprejudiced patriot.

The hole reference nearest in temporal proximity to the murder itself is the following, a rather visceral description of the lascivious baron as he flirts with 
the prostitutes:

[...] le baron de Kelweingstein, lâche dans son vice, rayonnait, lançait des mots grivois, semblait en feu avec sa couronne de cheveux rouges. Il galantissait en français du Rhin; et ses compliments de taverne, expectorés par le trou des deux dents brisées, anrivaient aux filles au milieu d'une mitraille de

salive. (392-93)

The baron's sexual arousal is clear in this non-narrative portrait. His "vice" and his "mots grivois" show his intentions, and the narrator's more subtle use of the verb "lâche" and adjective "expectorés" evoke potentially sexual concepts of bodily release. His red hair, a frequent sign of sexual fervor in Maupassant's writing, complement the sexual nature of the portrait. But perhaps the most powerful figure of the passage is the rather oxymoronic "mitraille de salive". When juxtaposed in the context of this passage, the metaphor of the machine gun and the concept of saliva produce the image of a bodily violence that will only be paralleled by Rachel's stabbing of Eyrik, in the gesture itself.

An excerpt from the murder sequence is useful at this point: Rachel, having controlled her temper during Eyrik's insults of both the army and the women of France, delivers her most appropriate insult possible, then acts:

" [...] Je ne suis pas une femme, moi, je suis une putain ; c'est

bien tout ce qu'il faut à des Prussiens. "

Elle n'avait point fini qu'il la giflait à toute voléc; mais

comme il levait encore une fois la main, affolée de rage,

elle saisit sur la table un petit couteau de dessert a lame

d'argent, et si brusquement, qu'on ne vit rien d'abord, elle

le lui piqua droit dans le cou, juste au creux où la poitrine

commence.

Un mot qu'il prononçait fut coupé dans sa gorge; et

il resta béant, avec un regard effroyable. (395)

Scveral aspects of this passage deserve mention. First, the position of the adjective "affolec" in the sentence is a syntaxic reminder of both sexual ambiguity and difference. Upon reading this word, one is not sure whether it qualifies a previously named object, "la main", or perhaps even Eyrik himself, given the preceding narrative precedents of androgynous pronoun interchangeability. Second, the "lame d'argent" of the dessert knife echoes the symbolically charged hidden silver, which, as stated above, later becomes a metaphor for both the clock tower and Rachel herself in retrospect. The third, and doubtless most important, aspect of this passage is the description of the area of Eyrik's body where Rachel plunges the knife: "juste au creux où la poitrine commence". This "creux", the text's last hole image, turns all previously mentioned holes into a series of markers that ultimately foreshadow not Eyrik's death as such, but the pictorial and corporeal geography of his murder. 
Sexually ambiguous descriptions of Eyrik, the noticeable lack of descriptive networks in representations of Rachel, and the problematic, recurring figure of the hole in the poetics of a physically described act (the murder) make sexual difference itself impossible to isolate. Visuality does serve sexual difference, though, in "Mademoiselle Fifi", in a very specific way: it exploits the reader's difficulty in matching the clear binarity of, say, the banquet/murder sequence with that of polar sexual opposites. This is primarily the work of description, although it could be considered more specifically an issue of perspective, as illustrated by the narrator's avoidance of the prostitute character's psychology. Eliane Lecarme-Tabone, for instance, notes,

[...] il est rare que la prostituée soit le personnage focal ou

que ses sentiments et ses pensées fassent l'objet d'une analyse,

même si son noin sert de titre à la nouvelle. Dans Mademoiselle

Fifi et La Maison Tellier, le narrateur ou bien reste à l'extérieur

à tous ses personnages dont il décrit les comportements et

rapporte les paroles, ou bien passe d'un point de vue à l'autre

très rapidement et souvent sans expliciter son choix. (113)

Maupassant's narrator, it is true, risks almost no sharing of point-of-view by means, for example, of free indirect discourse. "Mademoiselle Fifi", a textual terrain pock-marked by criss-crossing, visual descriptions of holes and contradictory gender signals, makes any clear elucidation of sexual distinction virtually impossible. Indeed, it seems that the very act of looking for sexual difference is the reader's fundamental task in this text. 


\section{Notes}

' See Michael Howard's The Franco-Prussian War: The German Invasior. of France, 1870-71 (New York: Macmillan, 1962), in which the author argues that France's defeat was due to its underdeveloped industrial technology.

\section{Works Cited}

Lecarme-Tabone, Elaine. :Enigme et prostitution." Maupassant miroir de la nouvelle. Proc. of the 1988 Colloque de Cérisy. Ed. Jacques Lecarme and Bruno Vercier. Saint-Denis: Presses Universitaie de Vincennes, 1988. Maupassant, Guy dc. Contes et nouvelles. Ed. Louis Forestier. Vol. 1. Paris: Gallimard, 1974. 2 vols. Noël, Bernard. Journal du regrd. Pris: P.O.L., 1988. 
